\title{
PLANT SPECIES RICHNESS ON AN ELECTRIC TRANSMISSION RIGHT-OF-WAY USING INTEGRATED VEGETATION MANAGEMENT
}

\author{
By Richard H. Yahner and Russell J. Hutnik
}

\begin{abstract}
The State Game Lands (SGL) 33 Research and Demonstration Area, Centre County, Pennsylvania, U.S., has been studied each year since 1953, making this 52-year old project extremely valuable as a source of information on the effects of mechanical and herbicidal maintenance on flora and fauna along an electric transmission right-of-way (ROW). A desired objective of integrated vegetation management on the SGL 33 Research and Demonstration Area is to create a diversity of plant species. In this paper, our objective was to document plant species richness among treatment units and in relation to wire and border zones on the SGL 33 Research and Demonstration Area. We noted the presence of plant species from late May through mid-August in both 2003 and 2004 and observed 125 vascular plant species in the 15 treatment units. The total number of species per unit ranged from a low of 35 species in a mowing unit to a high of 63 species in a basal lowvolume spray unit. Of the total number of plant species found on the right-of-way, 95 (76\%) and 110 (88\%) occurred in wire and border zones, respectively. In wire zones, the average number of plant species ranged from 31 in mowing units to 41 in stem-foliage spray units. In border zones, the average number of plant species varied from a low of 34 in mowing units to a high of 41 in handcut units. The proportion of exotic species did not vary appreciably between wire and border zones (19\% and 22\% of total, respectively) on the ROW. However, the three units adjacent to unpaved state forest roads with high rates vehicular traffic not only had the highest number of total species in the unit ( 55 to 63 species) but also the highest number of exotic species (13 to 16 species). Hence, vehicular traffic and roadside management may be responsible in part for the invasion of seeds or other means of plant dispersal to these units. Because units relatively isolated from state forest roads tended to have fewer exotic species, these sections of the ROW can serve as refugia for native flora.
\end{abstract}

Key Words. Exotic species; herbicides; integrated vegetation management; rights-of-way; species richness; tree control; vegetation.

A major goal of the State Game Lands (SGL) 33 Research and Demonstration Project in central Pennsylvania, U.S., since 1987 has been to determine the use of Integrated Vegetation Management (IVM) for maintenance of an electric utility transmission right-of-way (ROW) (Bramble and Byrnes 1996; Yahner and Hutnik 2004a). The response of vegetation to IVM is important because plant communities can change within a relatively short time as a result of natural plant succession.
The IVM technique for vegetation along a ROW involves two phases: (1) the use of a herbicidal spray or mechanical treatment to initially control the density of target (undesirable) trees (i.e., those that have the potential of growing to a height that is not compatible with safe ROW maintenance) and (2) the development of a tree-resistant plant cover type to reduce target tree invasion of the ROW (Bramble and Byrnes 1996; Yahner and Hutnik 2004a). The wire-border zone method was used on all treatment units of the SGL 33 Research and Demonstration Project as a means of achieving this goal (Figure 1).

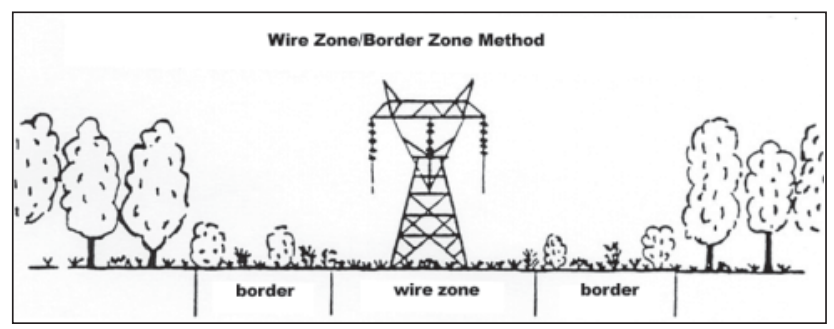

Figure 1. Diagram of a $230-\mathrm{kV}$ electric transmission line, showing wire and border zone. A combination of a lowgrowing, forb-shrub-grass cover type develops in the wire zone, and a tall shrub cover type occurs in the border zone. Adjacent to the border zone is mature forest.

The SGL 33 Research and Demonstration Area has been studied each year since 1953, making this 52-year-old project extremely valuable as a source of information on the effects of mechanical and herbicidal maintenance on flora and fauna along an electric transmission ROW (Yahner and Hutnik 2004a, 2004b). A desired objective of IVM on the SGL 33 Research and Demonstration Area is to create a diversity of plant species, which in turn provides a diverse wildlife habitat (Yahner and Hutnik 2004a). On a broad scale, habitat diversity on the ROW is achieved by herbicidal and mechanical maintenance of treatment units via the wireborder zone method. However, on a smaller scale, plant species diversity also is achieved by the presence of different combinations of shrub, forb, and grass cover types.

In this paper, our objective was to document plant species richness among treatment units and in relation to wire and border zones on the SGL 33 Research and Demon- 
stration Area. Species richness is a simple, yet important, measurement of species diversity and can be defined as the total number of different species in a given area (Yahner 2000).

\section{STUDY AREA AND METHODS}

The study area consists of 15 units, each of which was given a major treatment (mowing, mowing plus herbicide; stemfoliage spray; foliage spray; basal low-volume spray; and handcut) (Table 1) in 1987, 1993, 1996, and 2000 (see Yahner and Hutnik 2004a, 2004b for details of the treatments). Each treatment unit is rectangular in shape, ranges from 0.8 to 1.7 ha (2 to $4.2 \mathrm{ac}$ ), and spans the width of the ROW.

As part of the vegetation assessment of treatment units of plant species from late May through mid-August in both 2003 and 2004, the presence of each plant species was noted relative to wire versus border zone in each treatment unit. Only plants located at least $3 \mathrm{~m} \mathrm{(10} \mathrm{ft)} \mathrm{from} \mathrm{a} \mathrm{forest}$ access road arbitrarily were surveyed, thereby eliminating the counting of species immediately on the road edge.

\section{RESULTS AND DISCUSSION}

We observed 125 vascular plant species in the 15 treatment units on the SGL 33 Research and Demonstration Area during the 2 years (Table 1 and appendix). The total number of species per unit ranged from 35 species in a mowing unit (M-1) to 63 species in a basal low-volume unit (BLV-3) (Figure 2).

Another unit with a high number of plant species was a handcut unit (HC-2), which also was quite heterogeneous in plant structure (Table 1 and appendix). Two reasons for this heterogeneity is that this unit was originally a mowing unit and is in the process of being converted to a handcut unit (Yahner and Hutnik 2004b). Hence, it has mowed areas on one portion and woody areas on another portion of the wire zone, which was quite rocky and difficult for a mower to treat the unit. Furthermore, the southern portion of this unit was once traversed by an unimproved dirt road, which likely facilitated dispersal of seeds into this area.

Of the total number of plant species found on the ROW, 95 (76\%) and 110 (88\%) occurred in wire and border zones, respectively (Table 1 and appendix). In wire zones, the average number of plant species ranged from 31 in mowing units to 41 in stem-foliage spray units. In border zones, the average number of plant species varied from a low of 34 in mowing units to a high of 41 in handcut units. Fourteen species were found only in wire zones, whereas 27 species were exclusive to border zones. Only five species occurred in all 15 units.

Of the total number of plant species, $23 \%$ were exotic species (Table 1 and appendix). This number is similar to $20 \%$ exotic plant species noted in unfragmented forest stands in Wisconsin (Rooney et al. 2004).

The proportion of exotic species did not vary appreciably between wire and border zones (19\% and 22\% of total, respectively) on the ROW (Table 1 and appendix). However, the three units adjacent to unpaved state forest roads with high rates of vehicular traffic (SF-2 and MH-3 adjacent to Hannah Furnace Road, BLV-3 bisected by Strawband Beaver Road) not only had the highest number of total species in the unit ( 55 to 63 species) but also the highest number of exotic species (13 to 16 species). Hence, vehicular traffic and roadside management (and perhaps disposal of unwanted landscape clippings and plants along the roadside) may be responsible in part for the invasion of seeds or other means of plant dispersal to these units. Other studies have
Table 1. The total number of plant species in wire and border zones of 15 treatment units at the State Game Lands 33 Research and Demonstration Area from late May through mid-August 2003 and 2004. The number of exotic species is given in parentheses.

\begin{tabular}{|c|c|c|c|c|}
\hline \multirow[b]{2}{*}{ Treatment } & \multirow[b]{2}{*}{ Replicate unit } & \multicolumn{3}{|c|}{ Number of species } \\
\hline & & Wire zone & Border zone & Either zone \\
\hline \multirow[t]{4}{*}{ Mowing } & M-1 & $22(1)$ & $32(1)$ & $35(1)$ \\
\hline & $\mathrm{M}-2$ & $39(3)$ & $35(1)$ & $46(3)$ \\
\hline & M-4 & $30(2)$ & $34(2)$ & $40(2)$ \\
\hline & Average & $31(2)$ & $34(1)$ & $40(2)$ \\
\hline \multirow[t]{3}{*}{ Mowing plus herbicide } & MH-1 & $34(6)$ & $38(1)$ & $48(5)$ \\
\hline & MH-3 & $43(10)$ & $41(5)$ & $60(13)$ \\
\hline & Average & $39(8)$ & $40(3)$ & $54(9)$ \\
\hline \multirow[t]{3}{*}{ Stem-foliage spray } & SF-1 & $34(3)$ & $39(1)$ & $43(3)$ \\
\hline & SF-2 & $47(10)$ & $41(8)$ & $55(13)$ \\
\hline & Average & $41(7)$ & $40(5)$ & $49(8)$ \\
\hline \multirow[t]{3}{*}{ Foliage spray } & F-1 & $29(1)$ & $32(1)$ & $38(1)$ \\
\hline & $\mathrm{F}-2$ & $36(5)$ & $37(3)$ & $49(6)$ \\
\hline & Average & $33(3)$ & $35(2)$ & $44(4)$ \\
\hline \multirow[t]{5}{*}{ Basal low-volume } & BLV-1 & $23(1)$ & $32(0)$ & $36(1)$ \\
\hline & BLV-2 & $32(1)$ & $41(2)$ & $47(2)$ \\
\hline & BLV-3 & $50(10)$ & $46(12)$ & $63(16)$ \\
\hline & BLV-4 & $31(0)$ & $31(0)$ & $39(0)$ \\
\hline & Average & $34(3)$ & $38(4)$ & $46(5)$ \\
\hline \multirow[t]{3}{*}{ Handcut } & $\mathrm{HC}-1$ & $27(0)$ & $41(3)$ & $42(3)$ \\
\hline & $\mathrm{HC}-2$ & $42(6)$ & $41(3)$ & $42(9)$ \\
\hline & Average & $35(3)$ & $41(3)$ & $47(6)$ \\
\hline \multicolumn{2}{|l|}{ All units combined } & $95(18)$ & $110(24)$ & $125(29)$ \\
\hline \multicolumn{2}{|c|}{ Number found exclusive to a zone } & $14(3)$ & $27(11)$ & $41(14)$ \\
\hline
\end{tabular}




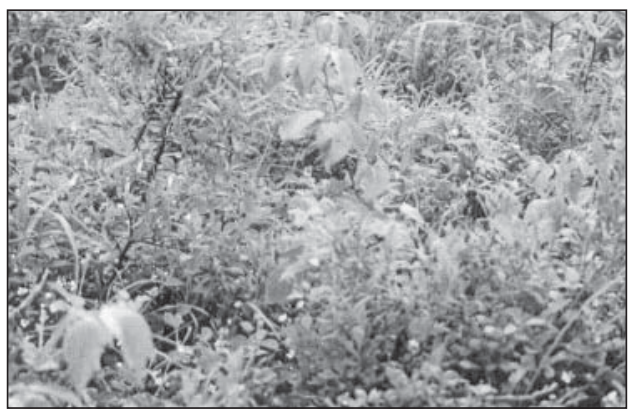

Figure 2. A basal low-volume spray unit (BLV-3). Note the diversity of plant species in this unit (photo credit: R. Yahner, July 2003).

found that exotic species were more common in forests and grassland near habitat edges, such as those at a road interface (Brothers and Spingarn 1992; Tyser and Worley 1992; Watkins et al. 2003; Pauchard and Alaback 2004). If forest roads in our study were paved, the number of exotic plant species could have been higher (Lundgren et al. 2004). Because units relatively isolated from state forest roads tended to have fewer exotic species, these sections of the ROW can serve as refugia for native flora (after Strittholt and DellaSalla 2001).

\section{LITERATURE CITED}

Bramble, W.C., and W.R. Byrnes. 1996. Integrated vegetation management of an electric utility right-of-way ecosystem. Down to Earth 51(1):29-34.

Brothers, T.S., and A. Spingarn. 1992. Forest fragmentation and alien plant invasion of central Indiana old-growth forests. Conserv. Biol. 6:91-100.

Lundgren, M.R., C.J. Small, and G.D. Dreyer. 2004. Influence of land use and site characteristics on invasive plant abundance in the Quinebaug Highlands of southern New England. Northeast. Nat. 11:313-322.

Pauchard, A., and P.B. Alaback. 2004. Influence of elevation, land use, and landscape context on patterns of alien plant invasions along roadsides in protected areas of south-central Chile. Conserv. Biol. 18:238-248.

Rhoads, A.F., and W.M. Klein, Jr. 1993. The Vascular Flora of Pennsylvania: Annotated Checklist and Atlas. American Philosophical Society, Philadelphia, PA. 636 pp.

Rooney, T.P, S.M. Wiegmann, D.A. Rogers, and D.M. Waller. 2004. Biotic impoverishment and homogenization in unfragmented forest understory communities. Conserv. Biol. 18:787-798.
Strittholt, J.R., and D.A. DellaSalla. 2001. Importance of roadless areas in biodiversity conservation in forested ecosystems: Case study of the Klamath-Siskiyou ecoregion of the United States. Conserv. Biol. 15:17421754.

Tyser, R.W., and C.A. Worley. 1992. Alien flora in grasslands adjacent to road and trail corridors in Glacier National Park, Montana (USA). Conserv. Biol. 6:253-262.

Watkins, R.Z., J. Chen, J. Pickens, and K.D. Brosofske. 2003. Effects of forest roads on understory plants in a managed forested landscape. Conserv. Biol. 17:411-419.

Yahner, R.H. 2000. Eastern Deciduous Forest: Ecology and Wildlife Conservation (2nd ed.). University of Minnesota Press, St. Paul, MN. 295 pp.

Yahner, R.H., and R.J. Hutnik. 2004a. Integrated vegetation management on an electric transmission right-of-way in Pennsylvania, U.S. J. Arboric. 30:295-300.

_ 2004b. State Game Lands 33 Research and Demonstration Project-52 Years of Continuous Study. Annual Report to Cooperators. 33 pp.

Acknowledgments. Cooperators were Asplundh Expert Tree Company, Dow AgroSciences, FirstEnergy (Penelec), and the Pennsylvania Game Commission. Thanks to R.T. Yahner for field assistance and to E. Hill for assistance in preparing the manuscript.

"School of Forest Resources

The Pennsylvania State University

University Park, PA, 16802, U.S.

"Corresponding author: Richard H. Yahner.

\section{APPENDIX}

The table on the following pages contains a list plant species (in phylogenetic order) noted in wire zones (W), border zones (B), in both zones (WB), or absent (- $\longrightarrow$ ) in 15 treatment units on the State Game Lands 33 Research and Demonstration Area from late May through mid-August 2003 and 2004. The replication of each treatment is given after each unit, where treatments are mowing $(\mathrm{M})$, mowing plus herbicide (MH), stem-foliage spray (SF), foliage spray (F), basal low-volume (BLV), and handcut (HC). Scientific names are taken from Rhoades and Klein (1993). 


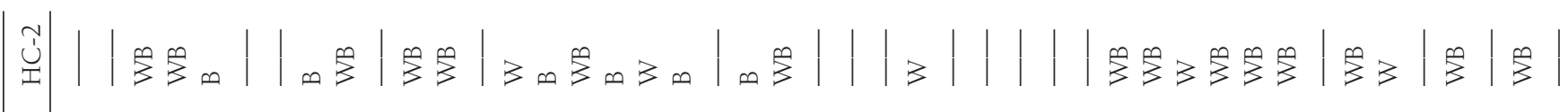

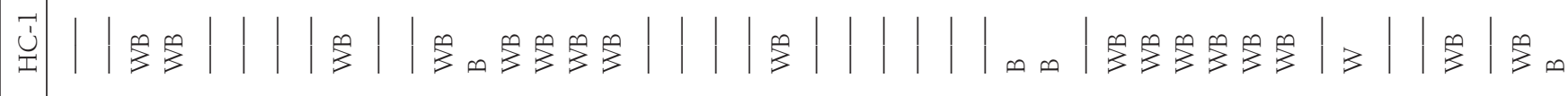

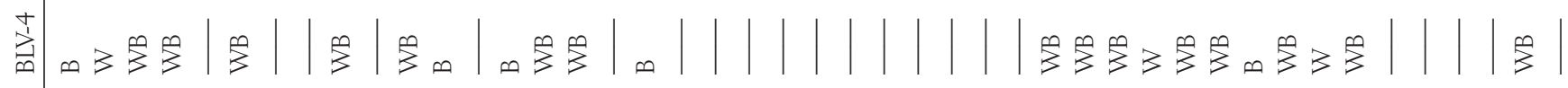
站

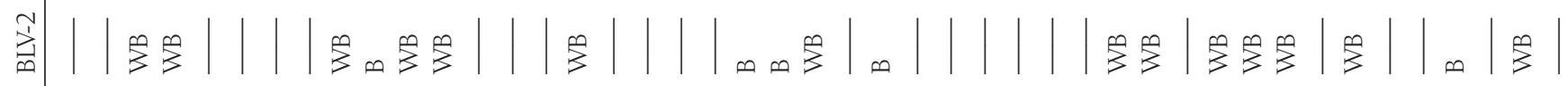

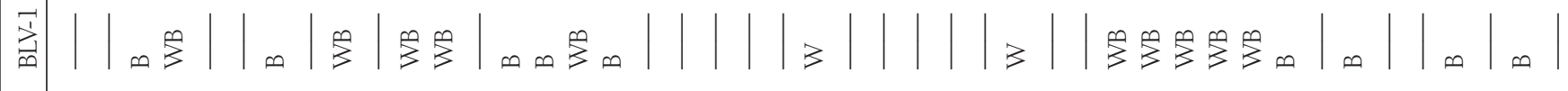

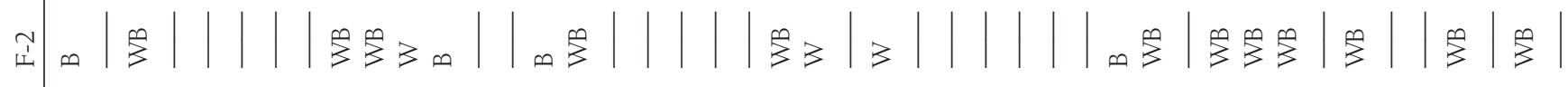

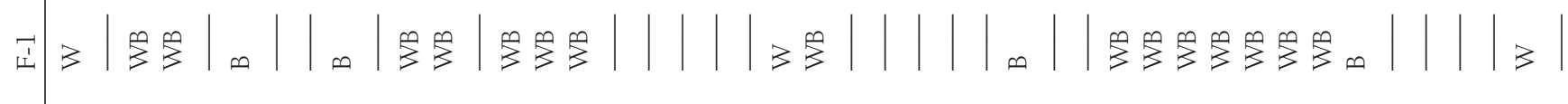

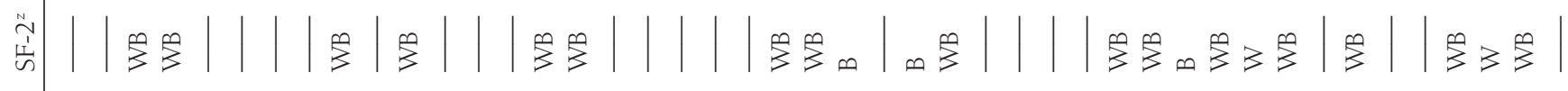

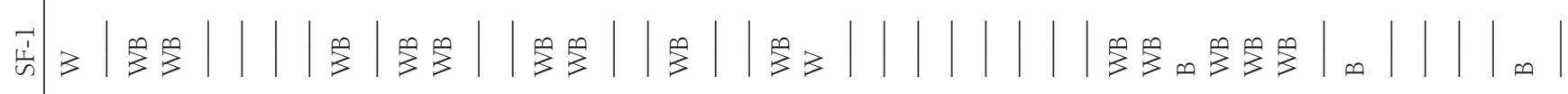

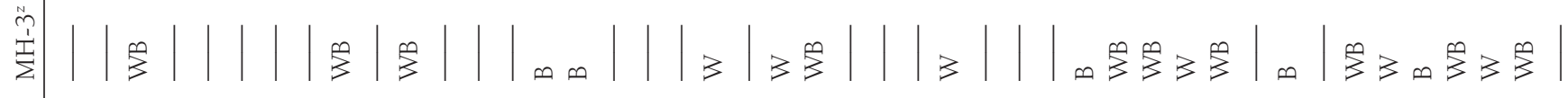
立

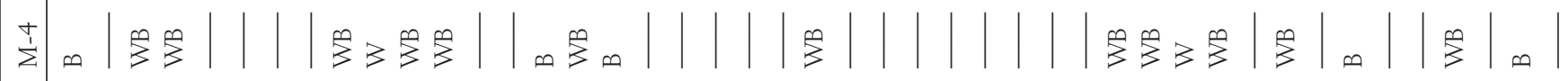

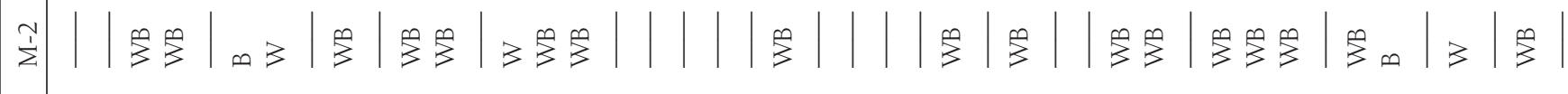

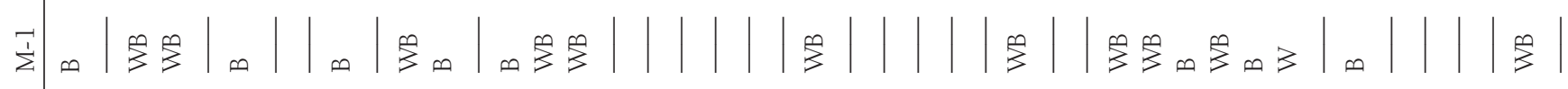

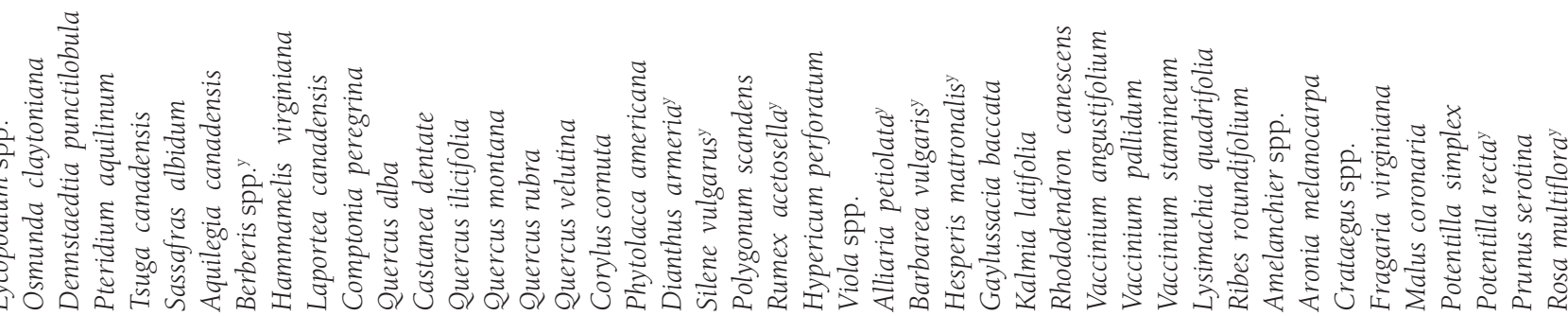




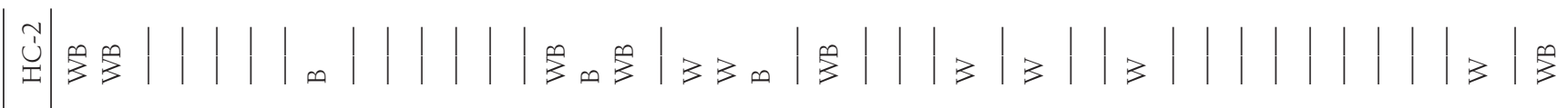

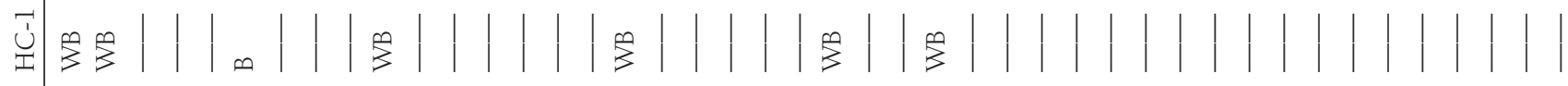

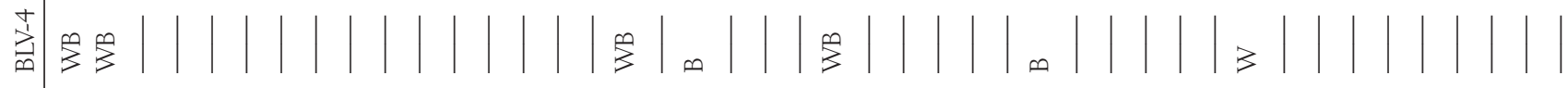

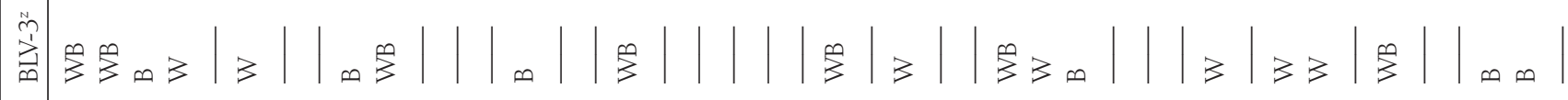

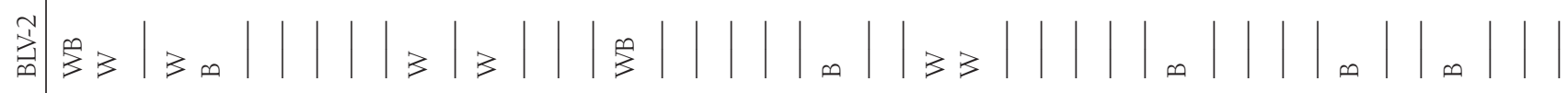

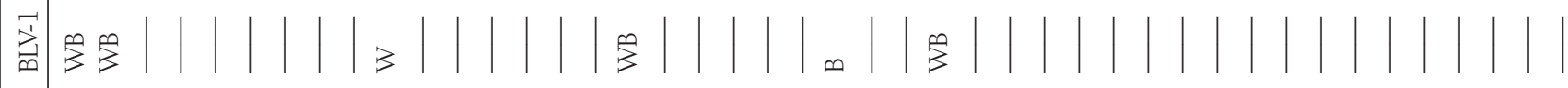

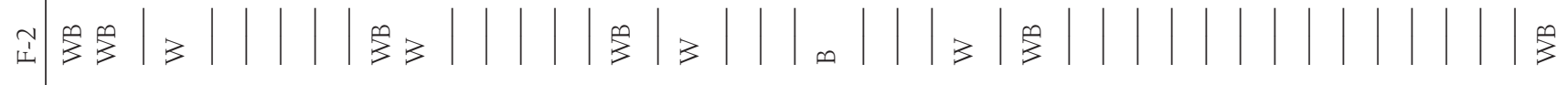

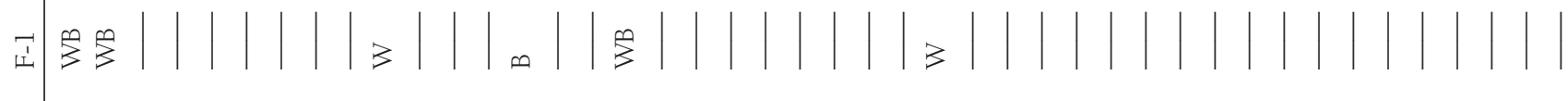

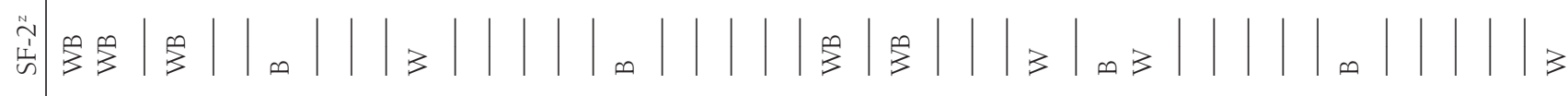

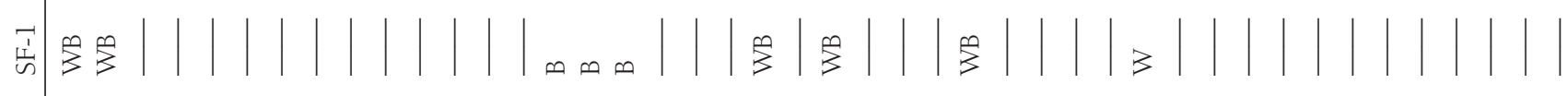

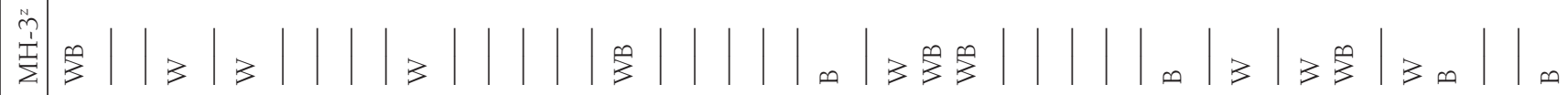

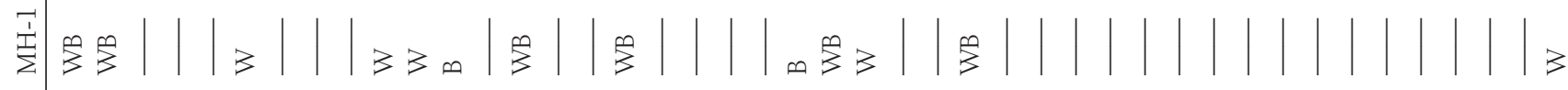

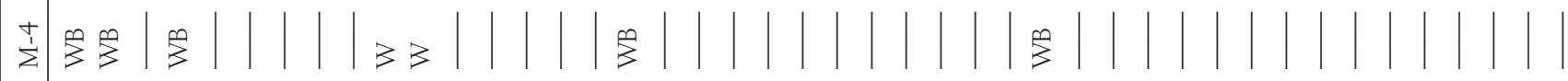

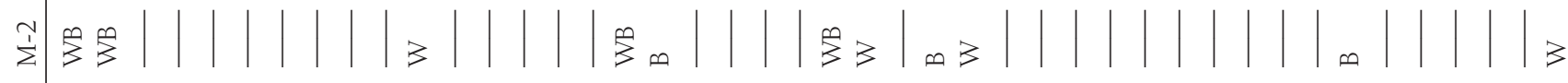

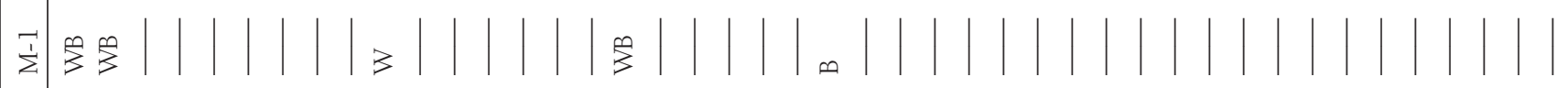

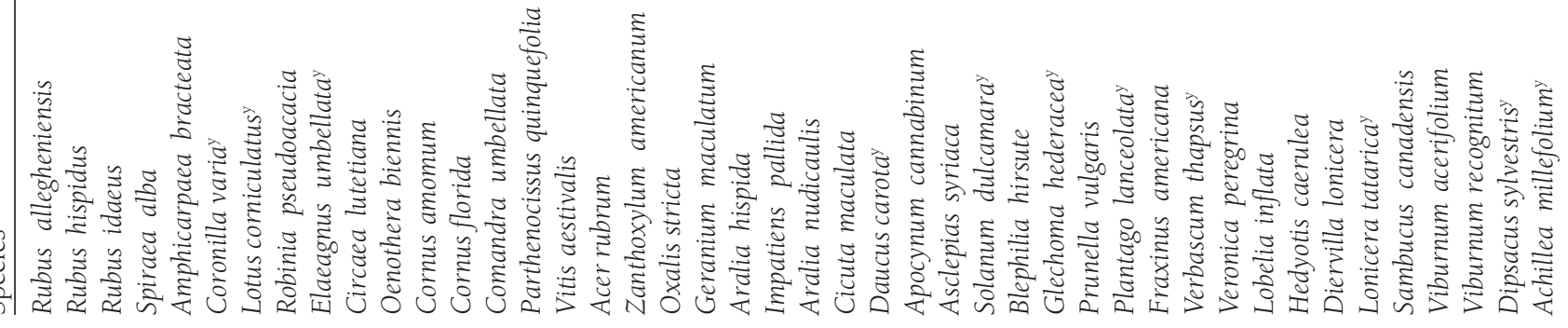




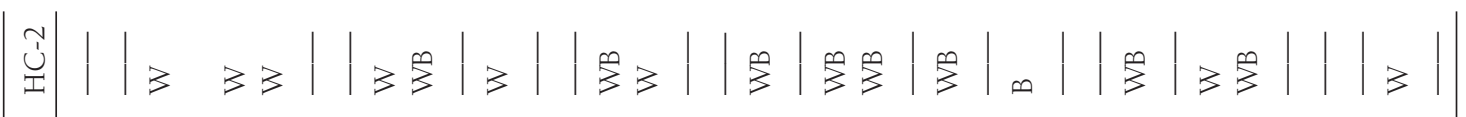

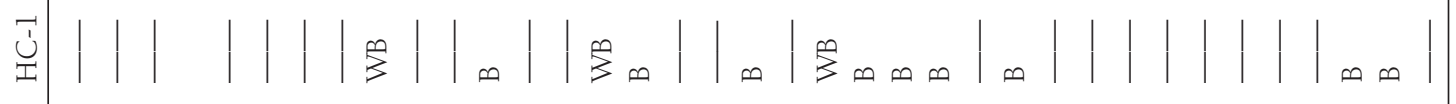

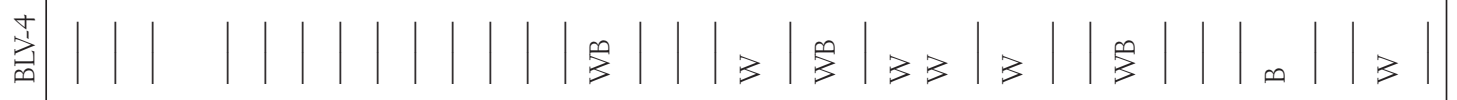

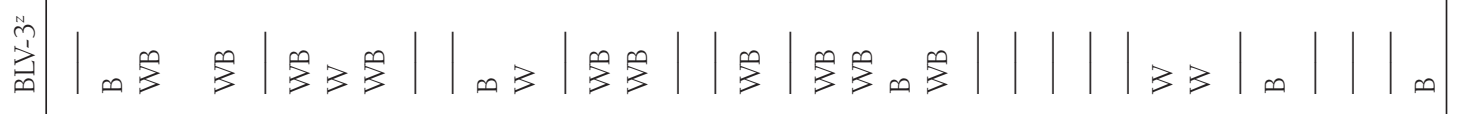

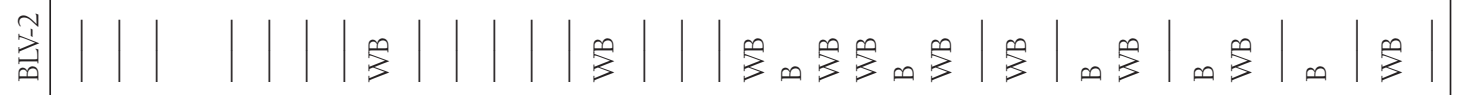

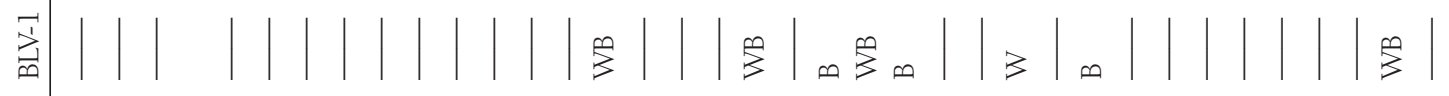

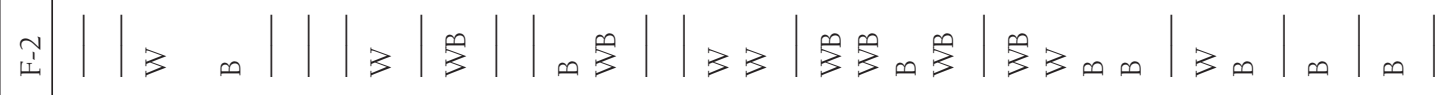

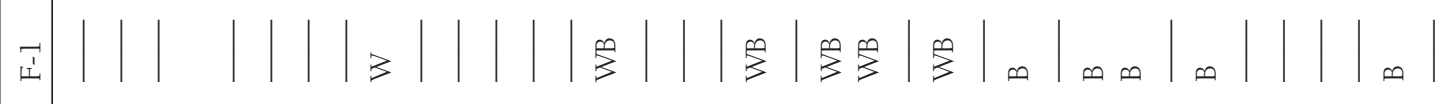

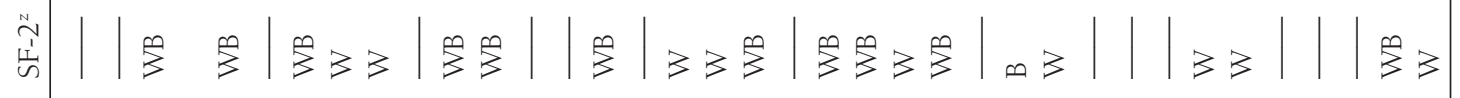

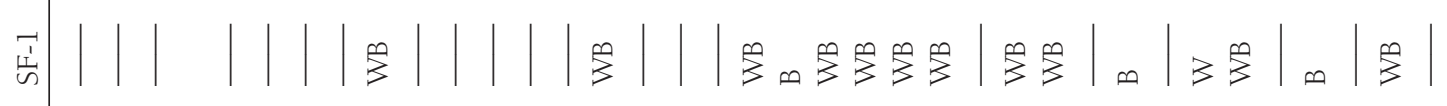
总

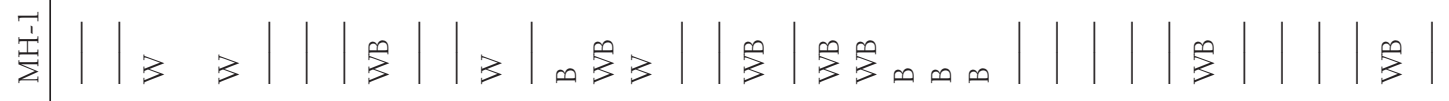

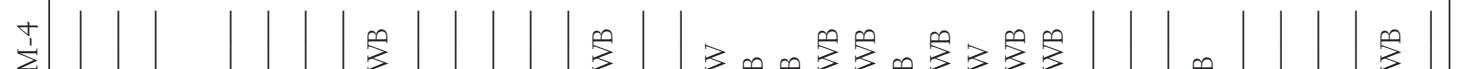

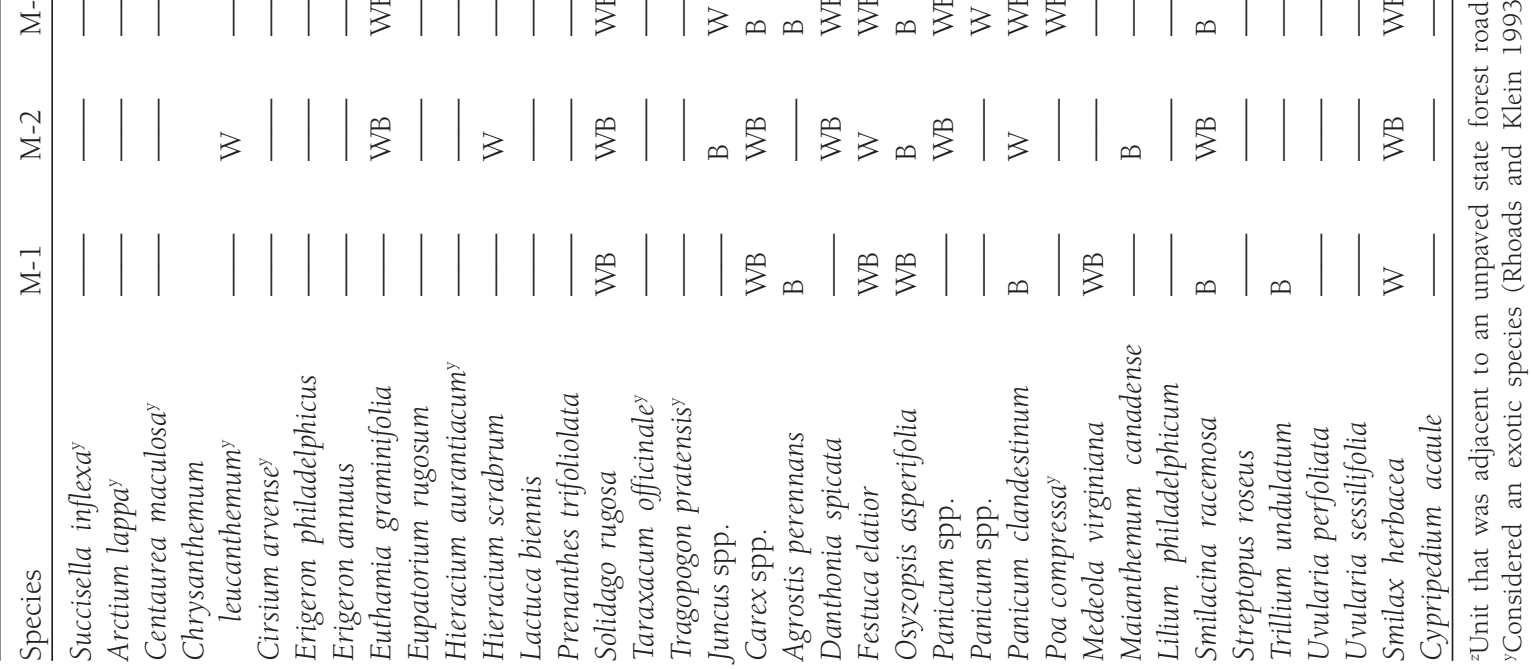


Résumé. Laire de recherche et de démonstration State Game Lands 33 du comté de Centre en Pennsylvanie a été étudiée chaque année depuis 1953, ce qui fait de ce projet vieux de 52 ans une source extrêmement utile d'informations sur les effets de l'entretien mécanique et chimique sur la faune et la flore d'une emprise de ligne électrique de transport. Un des objectifs recherchés de gestion intégré de la végétation sur l'aire de recherche et de démonstration SGL 33 est de créer une diversité d'espèces de plantes. Dans cet article, notre objectif était de documenter la richesse en plantes parmi les diverses unités traitées en relation avec la zone des fils ainsi qu'avec la zone latérale (en bordure) à ces derniers. Nous avons noté la présence des espèces de plantes de la fin mai à la miaoût en 2003 et 2004, ce qui a permis d'observer 125 espèces de plantes vasculaires au sein des 15 unités de traitements. Le nombre total d'espèces par unité variait de 35 au sein de l'unité fauchée à 63 au sein de l'unité coupée et traitée avec un herbicide. Du nombre total des espèces observées au sein de l'emprise, 95 (76\%) et 110 (88\%) espèces occupaient, respectivement, la zone des fils et la zone latérale à ces derniers. Dans la zone des fils, le nombre moyen d'espèces variait de 31 au sein de l'unité fauchée à 41 au sein de l'unité vaporisée sur le feuillage et les tiges. Dans les zones latérales aux fils, le nombre moyen d'espèces de plantes variait de 34 au sein de l'unité fauchée à 41 au sein de l'unité coupée manuellement. La proportion d'espèces non indigènes ne variait pas de manière appréciable entre la zone des fils et la zone latérale, soit 19 et 22\% du total respectivement. Cependant, les trois unités adjacentes à des routes forestières publiques non asphaltées avec une importante circulation de véhicule avaient non seulement le plus grand nombre total d'espèces indigènes par unité (de 55 à 63), mais aussi le plus grand nombre d'espèces non indigènes (de 13 à 16). De là, on peut en déduire que la circulation des véhicules et la gestion des abords de routes pourrait donc avoir eu une influence partielle sur l'invasion de ces unités par des semences ou d'autres méthodes de dispersion des plantes. Parce que les unités relativement isolées des routes forestières publiques tendaient à comporter moins d'espèces, ces sections de l'emprise d'étude pourraient servir de refuge pour la flore indigène.

Zusammenfassung. Die Forschungs- und Demonstrationsfläche des staatlichen Wildgebietes (SGL) 33in Centre County, Pennsylvania, USA wird seit 1953 jährlich untersucht und macht damit dieses nun 52 Jahre alte Projekt sehr wertvoll als Informationsquelle für die Auswirkungen von mechanischer Pflege und Unkrautbekämpfung auf die Flora und Fauna im Bereich von elektrischen Überlandleitungen (ROW). Ein gewünschtes Objekt integrierten Pflanzenschutzes im Bereich dieser Forschungs- und Demonstrationsfläche ist, eine Vielzahl von Pflanzen dort zu kreieren und zu erhalten. In dieser Studie war es ein Ziel, den Pflanzenreichtum zwischen den Behandlungseinheiten und in Beziehung zu Kern- und Randzonen zu dokumentieren. Wir notierten eine Pflanzenpräsenz vom späten Mai bis Mitte August in den Jahren 2004 und 2005 und beobachteten 125 vaskuläre Pflanzenarten in den 15 Behandlungseinheiten. Die absolute Anzahl der Arten per Einheit reichte von 35 Arten in einer gemähten Einheit bis hin zu 63 Arten in einer Einheit mit niedrigem basalen
Herbizideinsatz. Von der absoluten Anzahl der vorgefundenen Pflanzen unter der Überlandleitung tauchten 95 (76\%) in Kernund 110 (88\%) in Randbereichen auf. In Kernzonen (unter den Drähten) reichte die durchschnittliche Zahl von 31 in gemähten Einheiten bis zu 41 in Einheiten mit Blatt- und Stamm chemisch behandelten Pflanzen. In Randzonen variierte die Pflanzenzahl von 34 in gemähten Einheiten bis hin zu 41 in Handgeschnittenen Einheiten. Der Anteil der exotischen Pflanzen variierte nicht wesentlich zwischen Kern- und Randzonen (19\% und $22 \%$, entsprechend). Dennoch, die drei benachbarten Einheiten zu ungepflasterten Waldstraßen mit nicht nur hoher Verkehrsdichte hatten die höchste Anzahl an Arten überhaupt (55-63 Arten) und ebenfalls die höchste Anzahl an exotischen Arten (13-16 Arten). Daher kann der Fahrzeugverkehr und das Straßenmanagement teilweise verantwortlich für die Einfuhr von Samen oder anderer Pflanzenteile in diese Einheiten sein. Weil die relativ entfernten Einheiten von den staatlichen Waldstraßen eher zu weniger Arten tendierten, können die Sektionen der Überlandleitung als Refugium für einheimische Arten dienen.

Resumen. Desde 1953 el Área de Investigación y Demostración 33 de State Game Lands (SGL), en Pennsylvania, U.S., ha sido estudiada anualmente, haciendo de este viejo proyecto de 52 años una fuente valiosa de información de los efectos del mantenimiento mecánico y con herbicidas de la flora y fauna a lo largo del derecho de vía de las líneas de transmisión eléctrica (ROW). Un objetivo del manejo integrado de la vegetación en el Área de Investigación y Demostración SGL 33 es crear una diversidad de especies de plantas. En este reporte el objetivo fue documentar la riqueza de especies de plantas entre unidades de tratamiento y en relación a las zonas alambradas y zonas de frontera del área. Se notó la presencia de especies desde finales de Mayo hasta Agosto tanto en 2003 y 2004, se observaron 125 especies de plantas vasculares en las 15 unidades de tratamiento. El número total de especies varió de 35 en las unidades de segado a 63 en las de aplicación basal. Del número total de especies encontradas en el derecho de vía, 95 (76\%) y 110 (88\%) estuvieron en las zonas alambradas y de frontera, respectivamente. En las zonas alambradas, el número promedio de especies estuvo entre 31 en la unidades de segado a 41 en las unidades de aspersión del follaje. En las zonas de frontera, el número promedio de especies varió de 34 en las unidades de segado a 41 en las de corta manual. La proporción de especies exóticas no varió apreciablemente entre las zonas de alambre y de frontera (19\% y $22 \%$ del total, respectivamente) en el ROW. Sin embargo, las tres unidades adyacentes de carreteras estatales no pavimentadas con alto tráfico vehicular, no solamente tuvieron el más alto número total de especies (55-63 especies) sino también el más alto número de especies exóticas (13-16 especies). De allí que el tráfico vehicular y el manejo del ROW pueden ser responsables en parte por la invasión de semillas y otros medios de dispersión de plantas a estas unidades. Debido a que las unidades relativamente aisladas de las carreteras estatales forestales tienden a tener pocas especies, estas secciones de ROW pueden servir como refugio de flora nativa. 